\title{
Investigation and Countermeasure of Problems in Teaching Public Basic Courses of College Mathematics
}

\author{
Xiongwei Liu* \\ College of Science \\ National University of Defense Technology \\ Changsha, Hunan 410073, China \\ nudtlxw@163.com
}

\author{
Xiao Wang \\ College of Science \\ National University of Defense Technology \\ Changsha, Hunan 410073, China \\ wxiao_98@163.com
}

\begin{abstract}
To find out the cruxes of problems existing in teaching public basic courses of college mathematics, we investigated the possibly causes. To decrease the impacts and improve the quality of teaching, we suggested that we should update traditional teaching content to build an open practical course content system, optimize the teaching designs, methods and mean to construct a student-centered teaching mode, improve the teacher and student's evaluation methods to build a scientific and diversified evaluation mechanism and let the status of scholarship of teaching be clear and definite. Researches and practices show that our suggestions are effective and significant in improving the teaching of public basic courses of college mathematics.
\end{abstract}

Keywords-College mathematics, Public basic course, Teaching mode, Evaluation

\section{INTRODUCTION}

The public basic courses of college mathematics play an important role in mathematics education in our country. For those students whose major are not mathematics, these courses are even irreplaceable to promote the abilities of discovering, analyzing, exploring and solving problems and stimulate the innovative spirit. Therefore, how to efficiently achieve the education and teaching targets has always been a focus concerned by those teachers engaged in the teaching of these courses. Although we have made some achievements and progresses in reforms and explorations, some problems still exist. To investigate the existing problems, find out their crux and explore the ways to solve these problems is the key to improve the quality of teaching.

\section{THE OPEN PRACTICAL COURSES CONTENT SYSTEM}

Textbook is the basis of teaching and its content is the soul of a course. The choice and organization of the contents of a textbook directly determine whether it is attractive to students and has significance of existence. Because of the abstractness of college mathematics, through some contents appear in some mathematics textbooks of the middle school and students are familiar with them, but their knowledge is not enough systematic and rigorous[1]. For some contents of textbooks, the students more often can only see the abstractness of mathematics. The teaching process eventually is focused on the recitation of the formula and theorem proof and long calculation. The descriptions of the content in the textbook although emphasize that math has very wide applications in real life and emphasize the ability training to apply mathematical theory to solve practical problems, but for those applications in the teaching material, they mainly focus on descriptive words or are confined to geometric and physical application cases. The practical application cases which are close to the student's life are scarce in textbooks. These make students no intuitive impression and only generalizations. For the generation after 90s, they pay more attention to the perceptual, intuitive understanding. The teaching materials with the lack of practical application cases are hard to stimulate students' curiosity and the correct learning motivation.

In addition, there is overemphasis on completeness, formalization, abstraction and logic for the description and organization of the content. In textbook, a new concept is often followed by the theorem, formulas, proofs and samples. The whole process shows the perfection of mathematics, but students do not understand its meanings and values [2]. For the student whose major is not mathematics, only a few of them can be persistent to gain and a large number of them can't understand. This leads them to fear mathematics and feel that it is useless, and then they will lose the interest in learning mathematics, thus the goals of education and teaching can't be effectively achieved.

The curriculum content of mathematics generally came from practice, and can be confirmed by practice, and constantly accepts the inspection from the practice, and is developed in practice. Therefore, the content and organization of the textbook as the main learning materials should be centered on students. While the curriculum content of theories and methods can be ensured, the practical characteristics of mathematics should be fully embodied and the ideological, methodological, applicable and experimental characteristics should be strengthened. For example, textbooks should be integrated with application cases around students and related discipline's content; we should mathematize more modern relevant research results and the popularization of education and teaching should be strengthened; some practicable, exploratory and open questions and scene in which students can mathematically think, analyze, explore and solve problems 
should be set up. By integrating the mathematical culture, instructions of application background and the ideas and methods of mathematical modeling and experiment, we can reduce the difficulties which are caused by the abstraction of mathematics in the process of teaching and learning.

\section{THE STUDENT-CENTERED TEACHING MODE}

In teaching public basic courses of college mathematics, if integrities of courses and characteristics of students are not be accurately understood, we will be unable to do effective teaching design and choose the appropriate teaching methods to implement the teaching process by combining with the appropriate teaching means. Although in 2003, the teaching steering committee of the basic courses of mathematics for non-mathematics major of the ministry of education modified and issued again the basic teaching requirements of basic courses of mathematics for engineering undergraduates [3], but in teaching practice, due to the insufficient understanding and mastering, some teachers always take the limited class hours, too many teaching contents, large capacity of students and other objective factors as reasons and are unwilling to develop effective teaching support materials, then, artificially reduce the difficulty of some contents, simplify some necessary arguments, weaken mathematical thought, strengthen the calculation skills, emphasize the tests, replace the theoretical interpretation with application cases and present no expansion of the contents and so on. These make the teaching process boring and difficult, and can't arouse the enthusiasm of students' learning. Thus, the theory system can't be completely understood by students and the basic idea of mathematics, theoretical knowledge and methods can't be effectively mastered, which restrict the teaching effect to be achieved and cause the loss of the training goal of mathematics attainment and innovation ability.

In addition, teaching mode is limited to the traditional teaching mode which takes teacher as the main body of teaching. There is less or even no interaction in teaching and the method is single. The simplification of forms and methods lead inevitably to simplistic and narrow tendency of learning objectives, learning resources, learning space and time, learning style, learning experience and learning evaluation, etc. Although the teaching methods are renovated and the related course wares are developed, they can't be effectively integrated with the blackboard writing and multimedia [4].

In national medium and long-term education reform and development plan outline (2010-2020), it is pointed out that teaching heuristic, exploratory, discussion-based, participatory teaching modes are advocated. We should help the students learn how to study. Teaching should stimulate students' curiosity, cultivate the students' interests and provide a good environment for students' independent thinking, free exploration and innovation. We should develop some practical course contents and activity curriculum resources to enrich students' scientific experiment resources and promote the sharing of high quality teaching resources. The stratified teaching, class system, credit system, tutorial system and so on should be advanced to promote teaching reforms of management system. Teachers should strengthen the studies and trainings of education and teaching theories in order to grasp the intrinsic relationships of each component of public basic courses of college mathematics and the total goal and end-result. In teaching, teacher should change their education ideas according to the features of different colleges and universities, different disciplines and majors, pay attention to the ideological content of mathematics teaching, highlight scientific nature and practicality of mathematics.

The dominant position of students in teaching should be established and the growth education and all-round development of students should be taken as the fundamental value orientation of education and teaching. The teaching scene close to students' life should be built to carry out teaching activities by flexibly using a variety of teaching forms, designing a variety of teaching activities and with the aid of appropriate teaching methods. Meanwhile, the teaching organization forms and methods with only lecture should be reduced. With the aid of modern information technology, learning from examples, learning by doing, learning by exploration, learning from evaluation and so on, cooperated with the organization forms such as individual, group and class should be popularized. The method combined with lecturebased teaching, case teaching, autonomous teaching, discussion-based teaching, research teaching should be adopted.

\section{THE REASONABLE DIVERSIFIED EVALUATION MECHANISM}

Teaching evaluation is a process to evaluate teachers teaching and students' learning. It mainly includes the evaluation of classroom teaching for teachers and learning evaluation for students. As an important component of teaching process, it directly affects the overall function optimization of the teaching system. In general, for teacher's classroom assessment, each university has a uniform evaluation standard and establishes the corresponding teaching inspection section; it is carried out mainly by class visiting for teaching evaluation. At present, some universities establish online class evaluation system by which students can evaluate their teachers' classroom teaching. These appear seemingly comprehensive, objective, fair and just, but as the standardized evaluation, they are not so suitable to those teachers with individualized teaching style

The traditional way of student evaluation is mainly based on the course test scores. Such evaluation standard can't essentially explain what students have actually learned and can ultimately do and why the persons with poor grade in society can make great achievements. It is not conducive to the individualized and comprehensive development of students. Its defects are mainly as follows. It serves often screening and selection and lacks of spirit to promote the development of the learner, ignores the individual differences. It also confuses knowledge and ability, process and method. The paper test is the main test method and the participation and interaction, the self-assessment and mutual evaluation are not considered. It places too much emphasis on summative evaluation and the course scores, but ignores the formative evaluation and process evaluation.

The evaluations are only the evaluation means, not the purpose. Teaching evaluation must abide by objectivity 
principle, integrity principle, guiding principle, scientific principle [5-6]. The teaching evaluation should conform to the objective reality, not be arbitrary or be participated in personal emotion. A multi-angle, all-round evaluation should be carried out for all aspects of teaching activities. The teaching evaluation should not only be the evaluation, but provide the guidance for the teaching. There should be a reasonable unified evaluation criterion based on teaching goal from the unity of teaching and learning.

The evaluation for a student should take the development of learners as the center and adopt the diversified, personalized evaluation system beyond the traditional standard which places emphasis on the course test. The evaluation based on process should be put forward instead of the evaluation based on results. The evaluation standard should fully reflect learners' diversified viewpoints and varied solutions to problems. It also should pay more attention to self-reference, the flexible migration of knowledge and skills, the process of forming learners views and the sustainability, instantaneity, ecology of evaluation [5].

\section{THE SCHOLARSHIP OF TEACHING}

For the non-normal colleges and universities or research institutions, teaching researches are usually not considered as a kind of academic research. To some extent, teaching research results are regarded as one of just dispensable reference standards in the teachers' evaluation mechanism. These greatly reduce passion and enthusiasm of teachers' teaching research in order to improve the teaching quality. As a university centered on students, teaching research should be regarded as an academic research and its values should be admitted. The teachers should be motivated to engage in teaching research work.

Now the status of the scholarship of teaching is as follows [7-8]: Firstly, the teachers' evaluation system can't reflect the importance of teaching research to a certain extent, the center position of teaching should be established in universities. These make teachers unwilling to research teaching to improve teaching quality. There are even some teachers who regard teaching researches as a kind of burden, because there are almost no correlations with the title and the evaluation standard for teachers. It still focuses on how many scientific research papers are published and how many research subjects are supported. Secondly, for those teachers who are long engaged in public basic courses of college mathematics, they rarely have the chances to apply for and preside over the teaching research projects. According to the current requirement of project application and the way of review, those teachers who have senior or other titles, the related research foundation and reputation will have more chance to obtain supports. But, it is difficult to meet these standards and get supports for the frontline teachers, so they will probably lose the motive force to improve teaching quality. Thirdly, teaching researches are divorced from teaching practices. The education and teaching research results are seldom brought into the public and shared. Finally, the researches and practices on how research achievements are transformed into practical teaching content are scarce. The tasks of scientists are not just to find new truths and exchange new findings among counterparts; they should also present the new knowledge and findings by the comprehensible way [9].

The recognition of teaching research academic status not only can reflect the diversity of research contents in university, also inspires teachers to better serve teaching. At the same time, it embodies the "people-oriented" tenet in colleges and universities. When a university teacher attaches great importance to the teaching research in the thoughts and does teaching research in practice, one can truly become a welcome, respectable and outstanding teacher [11]. In order to encourage teachers to pay attention to teaching, the center position of teaching should be strengthened and the teaching research should have the same status as scientific research. A good teaching research environment and a scientific evaluation system should be built in order to ensure that teachers have the freedom of teaching and research and the multi-channel exchanges with counterparts, and to improve teachers' professional development of the scholarship of teaching [12]. Teaching projects should tend to easily be supported for those front-line teachers. The university should motivate teachers to engage in teaching and research work and encourage teachers to transform scientific research contents into easy-to-read teaching contents and teaching cases. The teaching research results should also be open and shared and a sharing mechanism of research achievements should be built.

\section{CONCLUSIONS}

In recent years, with the expansion of enrollment in colleges and universities, the employment situation of college graduates is more and more serious. The students' learning goals and purposes become more practical and clear, which lead some public basic courses, such as the abstract college mathematics, not to be attractive to students in the learning process. It is very difficult to stimulate students' interest in learning and correct learning motivation. At the same time, there are many problems as follows. For example, teaching contents and materials don't really reflect the personnel training goal and the teaching idea, the methods are single, textbooks are not understood enough deeply, teaching evaluation and method are not fit for the talents training goal, teaching can't get approval, etc. Therefore, the investigation on existing problems in the teaching and analysis on the cause of the problems are of great significance for seeking for the corresponding countermeasures to avoid teaching reform into the erroneous zone and improve the teaching quality to realize the talents training target to conform to the social needs.

\section{REFERENCES}

[1] Q. Wu, J.P. Li, J.M. Zhu, The Estimation and Analysis of Countermeasures of Middle School Mathematics' Modernization Influenced to the Advanced Mathematics' Teaching. College Mathematics, Vol.24, No.4, pp. 10-13, 2008. ( In Chinese)

[2] X.S. Zhang, Pay Attention to the Mathematical Ability Cultivation in Higher Mathematics Textbook Construction, Education and Teaching Forum, Vol.8, pp. 39-40, 2012. ( In Chinese)

[3] The teaching steering committee of the ministry of education for the basic courses of mathematics for non-mathematics major, The basic teaching requirements of basic courses of mathematics for engineering 
undergraduates(revised edition), College Mathematics, Vol.20, No.1, pp. 1-6, 2004. ( In Chinese)

[4] N. He, The problems and countermeasures existing in multimedia teaching. Heilongjiang Researches on Higher Education, Vol.1, pp. 127129, 2006. ( In Chinese)

[5] Q.F. Zhang, The teaching evaluation principle of "Two courses", Higher Education Exploration, Vol.2, pp. 81-83, 2006. ( In Chinese)

[6] Y.P. Zhang, The analysis on teaching evaluation principle, China Higher Education Research, Vol.10, pp. 48-48, 2001. ( In Chinese)

[7] H. Yin, University teachers' academic status and countermeasures for promotion, master's thesis, Hunan University, pp. 5-35, 2009. ( In Chinese)

[8] A.F. Zhang, M. Jin, Advocating academic teaching: the realistic choice to improve the teaching quality of colleges and universities, China University Teaching, Vol.11, pp. 20-23, 2010. ( In Chinese)
[9] Z.F. Dong, S.F. Wu, The value and main content of teaching academic research, Higher Education Exploration, Vol.2, pp. 84-88, 2013. ( In Chinese)

[10] Z.X. Zhong, Scholarship of teaching in open universities: connotations, significance and methods, Distance Education in China, Vol.9, pp. 10-23, 2012. ( In Chinese)

[11] C.J. Guo, On university teaching study makes a comprehensive positive role on teaching, Journal of Anyang Teachers College, Vol.1, pp. 116121, 2011. ( In Chinese)

[12] Y. Zhang, The value implication and system establishment of scholarship of teaching in the university, Journal of Higher Education, Vol.36, no.2, pp. 39-45, 2015.( In Chinese) 